Reprod. Nutr. Dévelop., 1987, 27 (6), 999-1003.

\title{
Effects of intrauterine infection by Staphylococcus aureus and Mycoplasma capricolum on the fertility of Nubian goats
}

\author{
A. A. SHALlali, A. M. HOMEIDA $\left({ }^{*}\right)$, E. A. DAFALLA $\left({ }^{* *}\right)$
}

Centra/ Veterinary Research Laboratory

P. O. Box 8067 Khartoum, Sudan

(*) Department of Veterinary Medicine, Pharmacology \& Toxicology University of Khartoum, P.O. Box 32, Khartoum North, Sudan

(**) Department of Veterinary Surgery, Obstetrics \& Gynecology, University of Khartoum, P.O. Box 32, Khartoum North, Sudan

Summary. Oestrous cycles were followed by blood progesterone titration and the occurrence of pregnancy was observed after mating in three groups of mature female Nubian goats. Two groups of 4 and 3 goats each were experimentally infected by an in utero injection of either a Staphylococcus aureus or a Mycoplasma capricolum strain of caprine origin. A third group of 4 goats served as a control. Both bacterial infections persisted in all experimental animals, except one, for at least 70 days. As a result, there is a shortening of the first two cycles and progesterone concentration was lower than in the controls. Only one inoculated goat became pregnant after the third oestrus. It is suggested that bacterial inflammation of the uterus may thus modify the oestrous cycle through the prostaglandin pathway.

\section{Introduction.}

Bacterial infection of the female genital tract, giving rise to bacterial toxins and inflammation, may influence the reproductive functions. It is well known that some Gram-negative infections cause abortion in domestic animals (Roberts, 1971). Experimental intrauterine infections at different stages of the luteal phase also affect the length of the oestrous cycle (Brinsfield et al., 1969). The purpose of this study was to investigate the effect of Staphylococcus aureus and Mycoplasma capricolum on corpus luteum regression and its consequences on reproductive functions in female Nubian goats.

\section{Material and methods.}

Eleven mature 3 to 4 -year old female Nubian goats with a normal oestrous cycles (19 to 21 days) were used. Oestrous (Day 0) was synchronized in all the 
goats by intramuscular injection of two doses $\left(8 \mathrm{mg}\right.$ each) of prostaglandin $F_{2, x}$ (Luteolyse, Upjohn, USA) 10 days apart. The animals came into oestrus 24 to $48 \mathrm{~h}$ after the second injection and were then divided randomly into three groups. Group I (nos. 1008, 1012, 1023 and 1028) included 4 goats used as an untreated control. Group II (nos. 1007, 1009, 1016 and 1018) included 4 goats inoculated with $1 \mathrm{ml}\left(18 \times 10^{8}\right.$ organisms) of Staphylococcus aureus (G 27 strain) by intrauterine route on Day 0 ; the bacterium was obtained from washing the uterus of goats in the Kassala Veterinay Clinic, Sudan. Group III (nos. 1029, 1032 and 1024) included three goats inoculated with $1 \mathrm{ml}\left(10^{9}\right.$ CFU) of Mycoplasma capricolum (O 37 strain) via intrauterine route ; this strain was obtained from the endometrial scrapings of sheep from the Omdurman slaughter house, Sudan.

Blood samples, obtained every two days by venipuncture using $23 \mathrm{G}$ needles and collected into chilled tubes, were centrifuged at $1800 \times \mathrm{g}$ for $10 \mathrm{~min}$; the plasma was separated and stored at $-30{ }^{\circ} \mathrm{C}$ until analysed for progesterone by radioimmunoassay (RIA). Weekly uterine washings were taken from the goats to reisolate the bacteria. Uterine washing was stopped for a complete cycle (21 days) after mating and resumed in those which failed to get pregnant. The goats were observed for one complete cycle. When they returned to oestrus, a fertile buck was introduced, mating was permitted lexcept for goats nos. 1008 and 1012 in Group 1), and the goats were observed for 10 weeks.

\section{Results.}

The results are summarized in tables 1 and 2. S. aureus and $M$. capricolum were reisolated from Groups II and III, respectively, in the first week after inoculation and thereafter until week 3 in goat 1007, week 8 in goats 1016 (Group II) and 1032 (Group III) and up to week 10 in the rest of the animals. No bacterium was isolated from the controls (Group |) ; goats 1023 and 1028 were checked for bacterium until week 3 .

Peripheral plasma concentrations of progesterone in Group 1 are given in table 2. All the goats had a functional corpus luteum, as shown by the progesterone levels which were about $3.5 \mathrm{ng} / \mathrm{ml}$ on Day 7 and $4.4 \mathrm{ng} / \mathrm{ml}$ on Day 14 of the oestrous cycle. On Days 20 to 21 of the oestrous cycle, all the animals returned to oestrus. The signs of oestrus were tail fanning, restlessness and acceptance of the male ; progesterone concentration was $<1 \mathrm{ng} / \mathrm{ml}$. The male was introduced on that day. Progesterone concentration on Days 7 and 14 in the second oestrous cycle was similar to that in the first cycle and goats nos. 1023 and 1028 did not return to oestrus. They were confirmed to be pregnant by their progesterone concentrations which were about $4 \mathrm{ng} / \mathrm{ml}$ on Day 22 of the second oestrous cycle (Day 42 of the experiment). Goats nos. 1008 and 1012 returned to oestrus 42 days after the experiment.

Peripheral plasma concentrations of progesterone in Groups II and III are summarized in table 1 . Three days after inoculation, the progesterone level increased to $1.5 \mathrm{ng} / \mathrm{ml}$ and then dropped suddenly to less than $1 \mathrm{ng} / \mathrm{ml}$ on Day 7 or 10 of the cycle. Only goats 1007 (Group II) and 1032 (Group III) exhibited behavioural oestrus. The second oestrous cycle was also shortened in these 


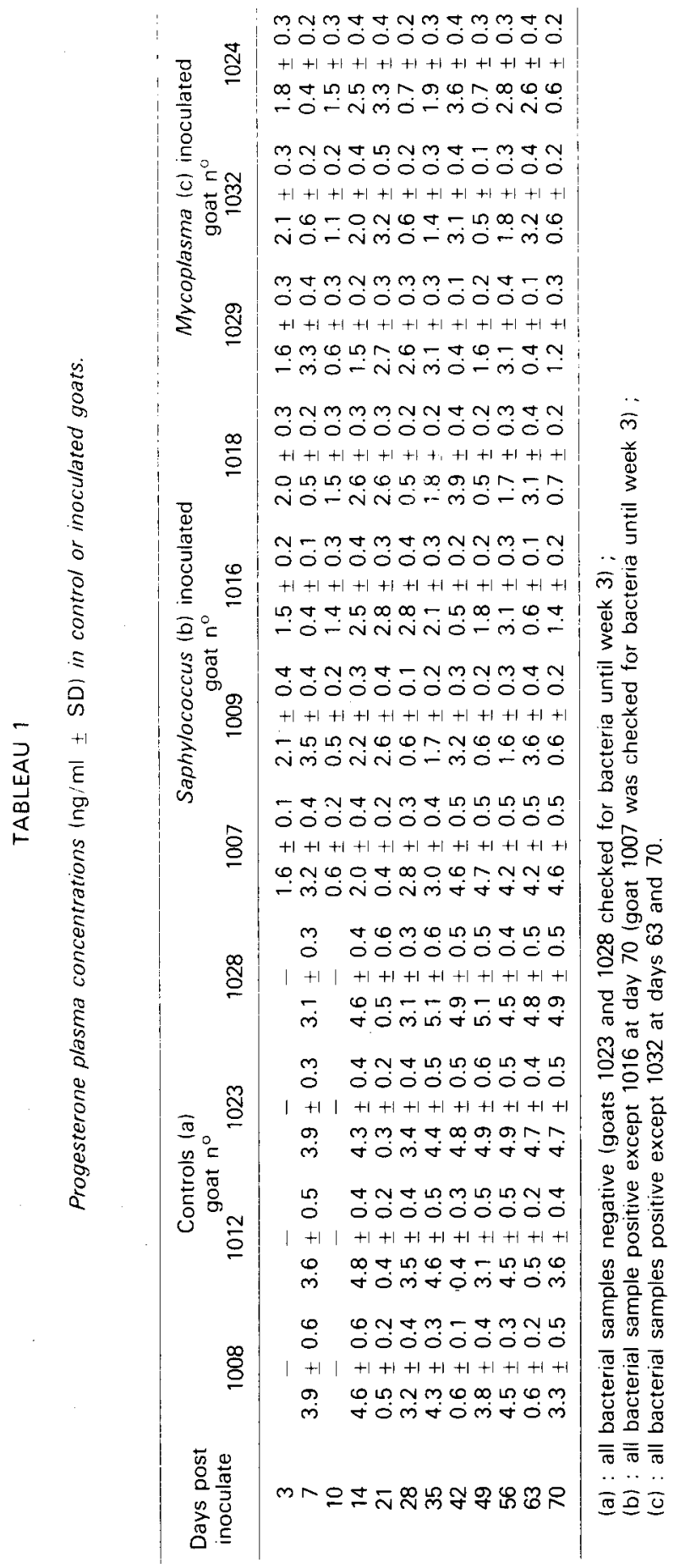


animals by at leas 14 days. They all showed behavioural oestrus. The length of the third oestrous cycle was about normal (18 to 21 days). Goat 1007 (Group II) did not return to oestrus and was pregnant 42 days after inoculation; its progesterone concentration was $4.8 \mathrm{ng} / \mathrm{ml}$ on that day.

During the oestrous cycle, progesterone concentrations in Groups II and III were significantly $(P<0.01)$ lower than in Group 1 .

\section{Discussion.}

The present results demonstrate that the life span of the corpus luteum in goats is shortened when bacterial infection is induced in the uterus on the day of oestrus. Similar results were obtained in ewes (Brinsfield and Hawk, 1968a ; Brinsfield, Higginbotham and Hawk, 1969). Such a mechanism apparently operates at least partly through the local utero-ovarian pathway (Brinsfield and Hawk, 1968b).

The effect of bacteria or bacterial toxins may be to cause inflammatory processes in the uterus. Prostaglandins have been found to be important mediators of inflammation (Veno et al., 1981). Prostaglandins, and prostaglandin $F_{2,2}$ specifically, are known to be luteolytic (Horton and Poyer, 1976). This may explain the shortening of the oestrous cycle in experimentally infected ewes and goats. Group II and III animals in the present study were observed to have significantly lower progesterone levels than the controls. This mays be due to partial luteolysis resulting from the low release of prostaglandin $\mathrm{F}_{2 x}$ which was not sufficient to cause complete regression of the corpus luteum; it has been reported that prostaglandin release induced by bacterial toxins and the subsequent occurrence of oestrus are dose-dependent in ewes (Friedricksson, Kindahl and Edquist, 1985). The present results suggest that bacterial infection in the uterus may affect reproduction, provided that enough bacterial toxins and inflammatory processes result to induce sufficient prostaglandin synthesis and release that will cause luteal regression.

In cases of uterine infection this might be partially beneficial since the release of prostaglandin induces oestrus and thus contraction of the uterus and renewal of uterine cellular elements which can aid the healing process (Fredriksson, Kindahl and Edquist, 1985). Such a phemonenon may have occurred in goats 1016 and 1032 which recovered spontenously. Although all infected goats showed short oestrous cycles, only one goat out of seven became pregnant. This may reflect reduced fertility in those animals. Studer and Morrow (1978) found a significant increase in the number of services per conception in infected cows, and Tennant and Peddicord (1968) showed a significant relationship between endometritis and decreased fertility in cows. This emphasizes the need to protect the uterus from bacterial contamination in order to avoid negative effects on the conception rate (Dekvuif and Brand, 1978). 
Résumé. Effets d'une infection intrautérine, par Staphylococcus aureus et Mycoplasma capricolum, sur la fertilité des chèvres nubiennes.

Le déroulement des cycles estriens de 3 groupes de chèvres nubiennes a été déterminé par dosage de la progestérone plasmatique, de même que l'existence d'une gestation après accouplement. Au début de l'expérience les cycles ont été synchronisés par injection de PGF2 $\alpha$. Un premier groupe de 4 animaux a servi de témoin. Les 4 chèvres du $2^{\mathrm{e}}$ groupe ont été infectées expérimentalement par injection in utero d'une suspension de Staphylococcus aureus et les 3 chèvres du $3^{\mathrm{e}}$ groupe, par une souche de Mycoplasma capricolum. L'infection a persisté dans toutes les chèvres injectées, à l'exception d'une seule, pendant les 70 jours d'examen. Les chèvres infectées ont montré un raccourcissement de la durée des deux premiers cycles et un niveau de progestérone significativement plus bas que celui des animaux témoins. II est suggéré que ces changements peuvent être liés à la sécrétion de PGF2cx par l'utérus. Une seule chèvre infectée est devenue gestante.

\section{References}

BRINSFIELD T. H., HAWK H. W., 1968a. Luteolytic effect of induced uterine infection in the ewe. J. amer. Sci, 27, 150-152.

BRINSFIELD T. H., HAWK H. W., 1968b. Stimulation by intrauterine devices of motility myometrium. J. Reprod. Fert., 16, 129-131.

BRINSFIELD T. H., HIGGINBOTHAM D. K., HAWK H. W., 1969. Influence of induced uterine infection at various stages of oestrous cycle on the corpus luteum of the ewe. J. anim. Sci., 29, 616-618.

DEKVUIF A., BRAND A., 1978. Factors influencing the reproductive capacity of a dairy herd N. Z. vet. J., 26, 178 and $183-189$.

FREDRIKSSON G., KINDAHL H., EDQUIST L. E., 1985. Endotoxin induced prostaglandin release and corpus luteum function in goat. Anim. Reprod. Sci., 8, 109-121.

HORTON E. W., POYSER N. L., 1976. Uterine Luteolytic hormone: A physical role for prostaglandin $\mathrm{F}_{2}$. Physiolo. Rev., 56, 595-651.

ROBERTS S. J., 1971. Veterinary obestetrics and genital diseases Ithaca, New York (Published by author), pp. 107-116, 135-137, 155-160.

STUDER E., MORROW D. A., 1978. Postpartum evaluation of bovine reproductive potential : comparison of findings from genital tract examination per rectum, uterine culture and endometrial biopsy. $J$. amer. vet. Med. Assoc., 172, 489-494.

TENNANT B., PEDDICORD R. G., 1968. Influence of delayed uterine involution and endometritis on bovine fertility. Cornell Vet., 58, 185-192.

VENO G. P., FRACASSO M. E., LEONE R., MILANINO R., 1981. Prostaglandin system and inflammation, 97-106. In, BERTI F., VENO G. P., The Prostaglandin system. Plenum Press, New York/London. 